\title{
Co-Digestion of Napier Grass and Its Silage with Cow Dung for Bio-Hydrogen and Methane Production by Two-Stage Anaerobic Digestion Process
}

\author{
Wipa Prapinagsorn ${ }^{1,2}$, Sureewan Sittijunda ${ }^{3}$ and Alissara Reungsang $1,4, *$ \\ 1 Department of Biotechnology, Faculty of Technology, Khon Kaen University, Khon Kaen 40002, Thailand; \\ wipa.p@hotmail.com \\ 2 Faculty of Agriculture, Uttaradit Rajabhat University, Uttaradit 53000, Thailand \\ 3 Faculty of Environment and Resource Studies, Mahidol University, Nakhon Pathom 73170, Thailand; \\ sureewan.sit@mahidol.edu \\ 4 Research Group for Development of Microbial Hydrogen Production Process from Biomass-Khon Kaen \\ University, Khon Kaen 40002, Thailand \\ * Correspondence: alissara@kku.ac.th; Tel./Fax: +66-43-362-121
}

Received: 14 November 2017; Accepted: 21 December 2017; Published: 26 December 2017

\begin{abstract}
The objective of this study was to efficiently utilize the napier grass and its silage to produce bio-hydrogen and methane by a two-stage process in batch mode. First, the production of hydrogen from a co-digestion of grass with cow dung and silage with cow dung by Clostridium butyricum Thailand Institute of Scientific and Technological Research (TISTR) 1032 was conducted. The results indicated that bio-hydrogen production by C. butyricum TISTR 1032 gave a higher hydrogen yield (HY) than without C. butyricum addition. The HY of 6.98 and $27.71 \mathrm{~mL} \mathrm{H}_{2}$ /g-Volatile solid added $\left(\mathrm{VS}_{\text {added }}\right)$, were obtained from a co-digestion of grass with cow dung and silage with cow dung by C. butyricum, respectively. The hydrogenic effluent and solid residue left over after hydrogen fermentation were further used as substrates for methane production (Batch I). Methane yield (MY) from hydrogenic effluent of grass with cow dung and silage with cow dung were 169.87 and $141.33 \mathrm{~mL} \mathrm{CH}_{4} / \mathrm{g}-\mathrm{COD}_{\text {added }}$ (COD: chemical oxygen demand), respectively. The maximum MY of 210.10 and $177.79 \mathrm{~mL} \mathrm{CH}_{4} / \mathrm{g}$-VS added, respectively, were attained from solid residues left over after bio-hydrogen production pretreated by enzyme (cellulase cocktail) and alkali ( $\mathrm{NaOH})$. Afterward, solid residue left over after methane production (Batch I) was used as the substrate for methane production (Batch II). A maximum MY of 370.39 and $370.99 \mathrm{~mL} \mathrm{CH}_{4} / \mathrm{g}-\mathrm{VS}_{\text {added }}$ were achieved from solid residue repeatedly pretreated by alkaline plus enzyme, respectively. The overall energy yield in the two-stage bio-hydrogen and methane production process was derived from a bio-hydrogen production, a methane production from hydrogenic effluent, methane production of pretreated solid residue (Batch I) and methane production of repeatedly pretreated solid residue (Batch II), which yielded 480.27 and $204.70 \mathrm{MJ} / \mathrm{g}-\mathrm{VS}_{\text {added, }}$, respectively.
\end{abstract}

Keywords: renewable energy; biomass; energy crop; biorefinery; biogas

\section{Introduction}

Hydrogen is a promising alternative energy source due to its clean, renewable and environmentally-friendly characteristics. It has zero carbon emissions after its complete combustion with oxygen [1]. Hydrogen has a high energy content, $122 \mathrm{KJ} / \mathrm{g}-\mathrm{H}_{2}$, which is about 2.75 times higher than that of hydrocarbon fuel [2]. In comparison to photo-hydrogen production, dark fermentation is receiving attention because it requires less energy and has a high hydrogen production rate [3-5]. Additionally, dark fermentation can utilize a wide range of substrates such as starch [6], glucose [7], waste activated sludge [8], 
rice straw [9], food waste [10], waste bread [11] and lignocellulosic biomass [12] to produce hydrogen. During dark fermentation, complex substrates are degraded to hydrogen, carbon dioxide and volatile fatty acid (VFAs), such as acetate, butyrate, propionate and ethanol.

Napier grass is one of the promising feedstocks for renewable energy production. Grass can be cultivated under a wide variety of conditions, implying that it can tolerate different land types, weather, and growing seasons. It also requires low inputs for growth [13-15]. Due to high biomass productivity of about $87 \mathrm{t} / \mathrm{ha}$ /year [16], the oversupply of grass can be preserved in the form of silage by the self-fermentation of grass under anaerobic conditions [17]. Silage is considered as a decent feedstock for anaerobic digestion (AD) $[17,18]$. Cellulose and hemicellulose were the main composition in grass and silage [19], with a cellulose content of approximately 35-50\% [14]. The hydrolysis of cellulose and hemicellulose yields fermentable sugars such as glucose, xylose, arabinose, mannose, and galactose as byproducts [20,21]. These fermentable sugars can be further used as a carbon source for energy production. However, the grass has a high carbon content (41.6\%), but is low in nitrogen content $(0.43 \%)$ [22], which makes a high ratio of carbon to nitrogen unsuitable for hydrogen production. Therefore, animal manure with a high percentage of nitrogen is co-digested with grass or silage in order to provide a suitable carbon-to-nitrogen ratio for hydrogen production by dark fermentation. Co-digestion offers several advantages over the use of a single substrate, including more balanced nutrients $(\mathrm{C} / \mathrm{N}$ ratio, macro-and micronutrients) and reduction of inhibitor/toxic compound accumulation [23-26], such as free ammonia/ammonium, which may occur during AD of manure alone [27].

A two-stage process consists of bio-hydrogen production, in the first stage, followed by methane production, in the second stage. The significance of a two-stage process includes process stability, higher biogas yield and, in particular, high total energy recovery. Pakarinen et al. [28] found that higher MY from silage ( $8 \%$ ) was obtained by a two-stage process in comparison to a one-stage process. Cavinato et al. [29] compared the single stage process with two-stage fermentation of organic waste and reported the overall energy recovery from the two-stage process was higher than single-stage fermentation.

Normally, bio-hydrogen production is always accompanied by volatile organic acid production, such as acetic, butyric, propionic acids, which can be further used to produce methane in the second stage. The utilization of hydrogenic effluent as the substrate for methane production can reduce a high chemical oxygen demand (COD) concentration in the effluent before disposal to the environment. The solid residue left over after bio-hydrogen production still contains cellulose as the main component. Pretreatment of solid residues generate glucose, which can be further used as the substrate for methane production. The pretreatment methods include physical methods such as grinding or milling [30], chemical methods such as acid or alkaline [31-33], biological methods such as microorganisms or enzymes [34,35] and combined pretreatments such as alkali plus enzymatic hydrolysis [36], alkali plus microwave pretreatment [32,37] and fungal plus milling pretreatment [38]. The choice of pretreatment technology must consider several factors e.g., the type of lignocellulosic biomass and a downstream biological conversion processes [39]. In this study, the pretreatment methods, including grinding, alkaline and enzyme treatment, as well as combined treatments of grinding plus enzyme, and alkaline plus enzyme were applied to pretreat the solid residues left over after bio-hydrogen production prior the use as the feedstock to produce methane in the second stage. This approach would efficiently utilize grass and silage as well as recovering energy from them.

Therefore, the aim of the present study was to evaluate the two-stage bio-hydrogen and methane process from the co-digestion of grass, silage and cow dung. An evaluation of the pretreatment methods of the solid residue left over after the bio-hydrogen production process was conducted. This approach would not only improve the substrate degradation efficiency, but also efficiently recover and gain energy from grass and silage. 


\section{Results and Discussion}

2.1. Bio-Hydrogen Production from the Co-Digestion of Grass with Cow Dung and Silage with Cow Dung by C. butyricum TISTR 1032

Hydrogen production from the co-digestion of grass with cow dung and silage with cow dung by C. butyricum TISTR 1032 was investigated under a mixing ratio of 3:1 g-volatile solid (VS)/g-VS. The modified Gompertz equation was found to fit the experimental data well with the $R^{2}$ coefficients of over 0.98 (Table 1). The results from the regression of a modified Gompertz equation for hydrogen production potential (HP) from a co-digestion of grass with cow dung and silage with cow dung by C. butyricum TISTR 1032 were 140 and $554 \mathrm{~mL} \mathrm{H}_{2}$ /L, respectively, and a hydrogen production rate (HPR) of 11.35 and $39.79 \mathrm{~mL} \mathrm{H}_{2} /(\mathrm{L} \cdot \mathrm{h})$, respectively, was obtained. A much lower HP of 43 and $51 \mathrm{~mL}$ $\mathrm{H}_{2} / \mathrm{L}$ was obtained from a co-digestion of grass with cow dung and silage with cow dung without an addition of C. butyricum, respectively, (Table 1). The trend of hydrogen yield (HY) was similar to the $\mathrm{HP}$ in which a maximum $\mathrm{HY}$ of 6.98 and $27.71 \mathrm{~mL} \mathrm{H}_{2} / \mathrm{g}$ - $\mathrm{VS}_{\text {added, }}$, were obtained from a co-digestion of grass with cow dung and silage with cow dung by $C$. butyricum, respectively. The lag times of hydrogen fermentation were shortened from 7.20 to $1.31 \mathrm{~h}$ and 6.28 to $0.24 \mathrm{~h}$ from a co-digestion of grass with cow dung and silage with cow dung by $C$. butyricum, respectively, in comparison to without C. butyricum TISTR 1032. The lag phase reflects the substrate degradation rate and correlates to the HP and HY. Therefore, an addition of C. butyricum TISTR 1032 into the fermentation system reduced the lag phase. This may be due to the fact that Clostridium sp. are cellulolytic bacteria capable of producing an extracellular enzymatic complex, called a cellulosome, that can digest cellulose very efficiently [40]. Consequently, more HP and HY were obtained (Table 1). In addition, C. butyricum is a well known hydrogen producer and has been reported to show the ability to utilize various kinds of substrates such as glucose [41], sugarcane syrup [41,42] and lignocellulosic biomass [43]. The concentration of soluble metabolite products (SMPs) in the fermentation broth with C. butyricum were higher than that without C. butyricum. In the fermentation of a co-digestion of grass with cow dung, acetate was the dominant metabolite ( $67 \%$ of total volatile fatty acids (TVFAs)), whereas in the fermentation of a co-digestion of silage with cow dung, acetate and butyrate were the major metabolites ( $47 \%$ and $48 \%$ of TVFAs, respectively). The distribution of acetate and butyrate over $40 \%$ (Table 1) in this fermentation system suggested that the main metabolic pathway of hydrogen production from a co-digestion of grass with cow dung and silage with cow dung by $C$. butyricum were acetate and butyrate type fermentation.

\subsection{Methane Production from Hydrogenic Effluent}

After the hydrogen fermentation process was ceased, the hydrogenic effluent was used to produce methane using anaerobic sludge as the inoculum. The methane production potential (MP) of 902 and $1002 \mathrm{~mL} \mathrm{CH}_{4} / \mathrm{L}$ from hydrogenic effluent from a co-digestion of grass with cow dung and silage with cow dung, respectively, were obtained (Figure 1). The methane content in all experiments ranged from $66-67 \%$ for both substrates. The methane production rate $(\mathrm{Rm})$ of 4.05 and $4.94 \mathrm{~mL} \mathrm{CH}_{4} /(\mathrm{L} \cdot \mathrm{h})$ from hydrogenic effluent from a co-digestion of grass with cow dung and silage with cow dung, respectively, were achieved (Table 2). Although the hydrogenic effluent from the co-digestion of grass with cow dung (5.31 g-COD added $)$ was less than that from silage with cow dung $\left(7.09 \mathrm{~g}-\mathrm{COD}_{\text {added }}\right)$, the MY from hydrogenic effluent from a co-digestion of grass with cow dung of $169.87 \mathrm{~mL} \mathrm{CH}_{4} / \mathrm{g}-\mathrm{COD}_{\text {added }}$ was higher than that from hydrogenic effluent from the co-digestion of silage with cow dung of $141.33 \mathrm{~mL}$ $\mathrm{CH}_{4} / \mathrm{g}$ - $\mathrm{COD}_{\text {added. }}$. This might be due to the fact that the hydrogenic effluent from the co-digestion of grass with cow dung contained a high concentration of acetic acid $(2.64 \mathrm{~g} / \mathrm{L})$, which distributed to $67 \%$ of acetic acid and $30 \%$ of butyric acid at the end of hydrogen production (Table 1). Acetate serves as a substrate for methane-forming archea [44] by promoting acetoclastic methanogens, resulting in a higher MY. The substrate conversion from hydrogenic effluent from a co-digestion of grass with cow dung (48\%) was higher than the hydrogenic effluent from the co-digestion of silage with cow dung $(40 \%)$, which correlated with the MY obtained (Table 2). The results indicated that the concentration of VFAs produced in the first stage also influenced the methane production in the second stage. At the end of the methane 
fermentation, a final $\mathrm{pH}$ between 7.60 and 7.75 were observed. The $\mathrm{pH}$ range of $7.0-8.0$ was suitable for biogas production and the degradation of VS [45].

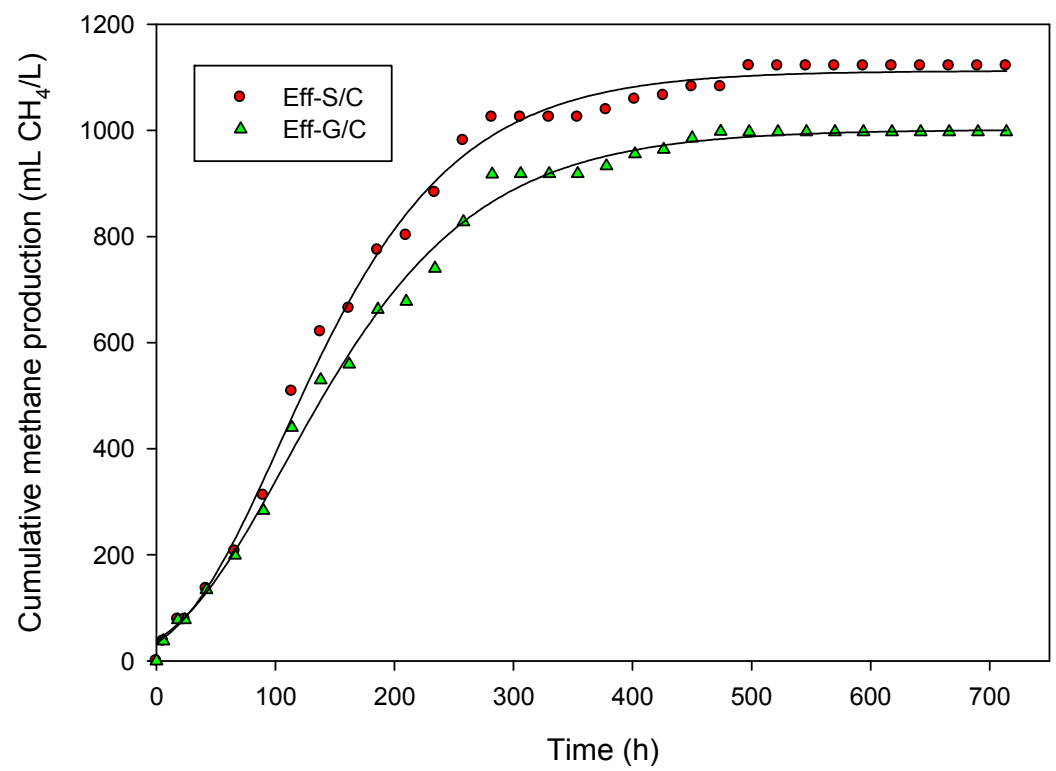

Figure 1. Profiles of cumulative methane production from hydrogenic effluent. Hydrogenic effluent from a co-digestion of grass with cow dung (Eff-G/C). Hydrogenic effluent from a co-digestion of silage with cow dung (Eff-S/C). 
Table 1. Bio-hydrogen production and soluble metabolite products (SMPs) from the co-digestion of grass with cow dung and silage with cow dung.

\begin{tabular}{|c|c|c|c|c|c|c|c|c|c|c|c|c|c|}
\hline \multirow{3}{*}{ Treatment } & \multirow{3}{*}{ Final $\mathrm{pH}$} & \multirow{3}{*}{$\mathrm{HP}\left(\mathrm{mL} \mathrm{H}_{2} / \mathrm{L}\right)$} & \multirow{3}{*}{$\begin{array}{l}\text { HPR (mL } \\
\left.\mathrm{H}_{2} /(\mathrm{L} \cdot \mathrm{h})\right)\end{array}$} & \multirow{3}{*}{ Lag Phase (h) } & \multirow{3}{*}{$R^{2}$} & \multirow{3}{*}{$\begin{array}{c}\mathrm{HY}(\mathrm{mL} \\
\left.\mathrm{H}_{2} / \mathrm{g}^{-\mathrm{VS}_{\text {added }}}\right)\end{array}$} & \multicolumn{7}{|c|}{ SMPs } \\
\hline & & & & & & & \multicolumn{2}{|c|}{ Acetic Acid } & \multicolumn{2}{|c|}{ Propionic Acid } & \multicolumn{2}{|c|}{ Butyric Acid } & \multirow{2}{*}{$\begin{array}{c}\text { TVFAs } \\
(\mathrm{g} / \mathrm{L})\end{array}$} \\
\hline & & & & & & & $(g / L)$ & $(\%)$ & $(\mathrm{g} / \mathrm{L})$ & $(\%)$ & $(\mathrm{g} / \mathrm{L})$ & $(\%)$ & \\
\hline G/C+ Clostridium butyricum TISTR 1032 & 5.02 & 140 & 11.35 & 1.31 & 0.98 & 6.98 & 2.64 & 67 & 0.12 & 3 & 1.20 & 30 & 3.96 \\
\hline S/C+Clostridium butyricum TISTR 1032 & 5.26 & 554 & 39.79 & 0.24 & 0.99 & 27.71 & 1.88 & 47 & 0.21 & 5 & 1.91 & 48 & 4.00 \\
\hline $\mathrm{G} / \mathrm{C}$ & 5.23 & 39 & 3.71 & 7.20 & 0.99 & 1.94 & 2.41 & 72 & 0.19 & 6 & 0.72 & 22 & 3.34 \\
\hline $\mathrm{s} / \mathrm{C}$ & 5.52 & 46 & 3.82 & 6.28 & 0.98 & 2.30 & 1.82 & 57 & 0.26 & 8 & 1.09 & 34 & 3.17 \\
\hline
\end{tabular}

G/C, S/C+ Clostridium butyricum TISTR 1032: Co-digestion of grass with cow dung, Co-digestion of silage with cow dung with Clostridium butyricum TISTR 1032 as inocolum; G/C, S/C:

Co-digestion of grass with cow dung, Co-digestion of silage with cow dung, without an addition of Clostridium butyricum TISTR 1032; HP: Hydrogen production potential (mL $\mathrm{H}_{2} / \mathrm{L}$ );

HPR: Hydrogen production rate ( $\mathrm{mL} \mathrm{H}_{2} /(\mathrm{L} \cdot \mathrm{h})$ ); HY: Hydrogen yield $\left(\mathrm{mL} \mathrm{H}_{2} / \mathrm{g}-\mathrm{VS}_{\text {added }}\right)$; TVFAs: (Total volatile fatty acids = Acetic + Propionic + Butyric). 
Table 2. Methane production potential (MP), methane production rate (Rm), methane yield (MY) from hydrogenic effluent.

\begin{tabular}{|c|c|c|c|c|c|c|}
\hline Effluent & Final $\mathrm{pH}$ & $\mathrm{MP}\left(\mathrm{mL} \mathrm{CH} \mathrm{CH}_{4} / \mathrm{L}\right)$ & $R m\left(\mathrm{~mL} \mathrm{CH}_{4} /(\mathrm{L} \cdot \mathrm{h})\right)$ & $\begin{array}{c}\mathrm{MY}(\mathrm{mL} \\
\left.\mathrm{CH}_{4} / \mathrm{g}-\mathrm{COD}_{\text {added }}\right)\end{array}$ & $\begin{array}{c}\mathrm{CH}_{4} \\
\text { Content }(\%)\end{array}$ & $\begin{array}{c}\text { Substrate } \\
\text { Conversion }(\%)\end{array}$ \\
\hline Eff-G/C & 7.75 & 902 & 4.05 & 169.87 & 66 & 48 \\
\hline Eff-S/C & 7.60 & 1002 & 4.94 & 141.33 & 67 & 40 \\
\hline
\end{tabular}

MP: Methane production potential $\left(\mathrm{mL} \mathrm{CH}_{4} / \mathrm{L}\right) ; \mathrm{Rm}$ : Methane production rate $\left(\mathrm{mL} \mathrm{CH}_{4} /(\mathrm{L} \cdot \mathrm{h})\right) ; \mathrm{MY}$ : Methane yield ( $\left.\mathrm{mL} \mathrm{CH}_{4} / \mathrm{g}-\mathrm{COD}_{\text {added }}\right)$.

\subsection{Methane Production from Solid Residues Left over after Hydrogen (Batch I) and Methane (Batch II) Fermentation Processes}

The solid residues left over after the hydrogen fermentation were pretreated by grinding as well as alkali and enzyme pretreatment before being used as the substrate to produce methane (Batch I). The regression of a modified Gompertz equation for MP and $\mathrm{Rm}$ is shown in Table 3. The maximum MP of 2849 and $2682 \mathrm{~mL} \mathrm{CH}_{4} / \mathrm{L}$, and the highest $\mathrm{Rm}$ of 12.51 and $11.33 \mathrm{~mL} \mathrm{CH}_{4} /(\mathrm{L} \cdot \mathrm{h})$ were obtained from the solid residue of grass with cow dung and silage with cow dung, respectively, pretreated by enzyme. Pretreated solid residue of grass with cow dung by enzyme gave a maximum MY of $210.10 \mathrm{~mL}$ $\mathrm{CH}_{4} / \mathrm{g}$-VS $\mathrm{V}_{\text {added. }}$. The enzymatic hydrolysis of grass yielded glucose that is a suitable substrate for methane production, resulting in a high MY.

Table 3. MP, Rm, MY from pre-treated solid residues.

\begin{tabular}{|c|c|c|c|c|c|c|}
\hline \multirow[b]{2}{*}{ Treatment } & \multicolumn{3}{|c|}{ Methane Production Batch I } & \multicolumn{3}{|c|}{ Methane Production Batch II } \\
\hline & $\begin{array}{c}\mathrm{MP}(\mathrm{mL} \\
\left.\mathrm{CH}_{4} / \mathrm{L}\right)\end{array}$ & $\begin{array}{c}R m(\mathrm{~mL} \\
\left.\mathrm{CH}_{4} /(\mathrm{L} \cdot \mathrm{h})\right)\end{array}$ & $\begin{array}{l}\text { Yield (mL } \\
\left.\mathrm{CH}_{4} / \mathrm{g}-\mathrm{VS}_{\text {added }}\right)\end{array}$ & $\begin{array}{c}\mathrm{MP}(\mathrm{mL} \\
\left.\mathrm{CH}_{4} / \mathrm{L}\right)\end{array}$ & $\begin{array}{c}R m(\mathrm{~mL} \\
\left.\mathrm{CH}_{4} /(\mathrm{L} \cdot \mathrm{h})\right)\end{array}$ & $\begin{array}{c}\text { Yield (mL } \\
\mathrm{CH}_{4} / \mathrm{g}-\mathrm{VS}_{\text {added }} \text { ) }\end{array}$ \\
\hline Sol-G/C-U & 851 & 3.36 & 62.72 & 70 & 2.76 & 3.65 \\
\hline Sol-G/C-G & 894 & 2.91 & 65.91 & 60 & 2.99 & 2.94 \\
\hline Sol-G/C-A & 2136 & 2.86 & 157.54 & 138 & 1.79 & 15.82 \\
\hline Sol-G/C-E & 2849 & 12.51 & 210.10 & 251 & 8.08 & 36.18 \\
\hline Sol-G/C-G+E & - & - & - & 196 & 7.78 & 26.30 \\
\hline Sol-G/C-A+E & - & - & - & 2113 & 8.71 & 370.39 \\
\hline Sol-S/C-U & 1044 & 2.62 & 54.47 & 83 & 1.97 & 1.72 \\
\hline Sol-S/C-G & 1231 & 3.15 & 64.20 & 130 & 3.02 & 9.75 \\
\hline Sol-S/C-A & 3408 & 3.13 & 177.79 & 103 & 1.39 & 5.04 \\
\hline Sol-S/C-E & 2682 & 11.33 & 139.92 & 170 & 8.27 & 16.54 \\
\hline Sol-S/C-G+E & - & - & - & 185 & 7.47 & 19.07 \\
\hline Sol-S/C-A+E & - & - & - & 2240 & 9.16 & 370.99 \\
\hline
\end{tabular}

Sol-G/C: Solid residue of grass with cow dung, Sol-S/C: Solid residue of silage with cow dung; U: untreated, G: grinding, A: alkaline pretreatment, E: enzyme pretreatment, G+E: grinded plus enzyme pretreatment and A+E: alkaline plus enzyme pretreatment.

Solid residue from a co-digestion of silage with cow dung pretreated with alkaline gave the maximum MY of $177.79 \mathrm{~mL} \mathrm{CH}_{4} / \mathrm{g}-\mathrm{VS}_{\text {added }}$. Alkaline destroys the crystalline structure of cellulose and increased the accessibility of cellulose for microbes. The study of Zhao et al. [46] reported that alkaline pretreatment efficiently decrease the crystallinity of cornstalks and an increased methane production efficiency was obtained. Crystallinity reduction is one of the main reasons for the pretreatment of lignocellulosic materials [47]. In this study, alkaline pretreatment increased methane production approximately over $100 \%$ in comparison to non-pretreatment for both substrates. The results are consistent with Frigon et al. [48] who reported that methane production from switch grass was increased over $50 \%$ after alkaline pretreatment.

The size reduction (or grinding) had a positive effect on the biodegradability of solid residues in which the MY of the grinded solid residue of grass with cow dung and silage with cow dung were 5.09 and $17.86 \%$ higher than the untreated sample. Grinding enhances the surface area of the biomass, reduces the degree of polymerization and the crystallinity of cellulose [49].

After the end of the methane production from the pre-treated solid residue, the solid residue left over after methane production was separated into two parts, i.e., directly used to produce methane and 
subjected to enzyme pretreatment before being used as feedstock for methane production (Batch II). The results found that the MP, Rm and MY from Batch II of each pretreatment method (untreated, grinding, alkaline pretreatment and enzyme pretreatment) decreased. In contrast, the MP, $R m$ and MY of both combined pretreatments were increased (Table 3). The maximum MY of 370.39 and $370.99 \mathrm{~mL} \mathrm{CH}_{4} / \mathrm{g}-\mathrm{VS}_{\text {added }}$ were obtained from the solid residue of a co-digestion of grass with cow dung and silage with cow dung pretreated with an alkaline plus enzyme pretreatment. This was due to the fact that alkaline treatment degrades the polymeric structures, especially lignin and hemicellulose, which made polymers accessible to enzymes as well as reducing their crystallinity [36]. Then, enzymes directly degrade the cellulose structure resulting in sugar. There was no inhibition of the microorganisms during the enzymatic digestion of lignocellulose biomass because toxic compounds were not produced [36]. Thus, the efficiency of methane production from solid residue pretreated by alkaline plus enzyme was higher than the other pretreatment methods.

The methane content in biogas produced during the methane fermentation processes by different pretreatment methods from one-stage fermentation (our previous experiments, [50]) and two-stage fermentation are shown in Figure 2. In the one-stage process, the sole enzyme pretreatment and the combined pretreatment had a methane content that exceeded $65 \%$ of the volume of biogas production (our previous experiments, [50]). In the two-stage process, the combined pretreatment gave a higher methane content in the range of $68-70 \%$ for both substrates (Figure 2). The results indicated that the combination of pretreatment methods improved methane production.

These results indicated that the combined alkaline plus enzymatic pretreatment had a great benefit on solid residue degradation as well as the AD process. Although the use of enzymatic hydrolysis increased the operation costs, the methane production increased manyfold. Therefore, the potential and feasibility on the use of enzymatic hydrolysis should be considered.

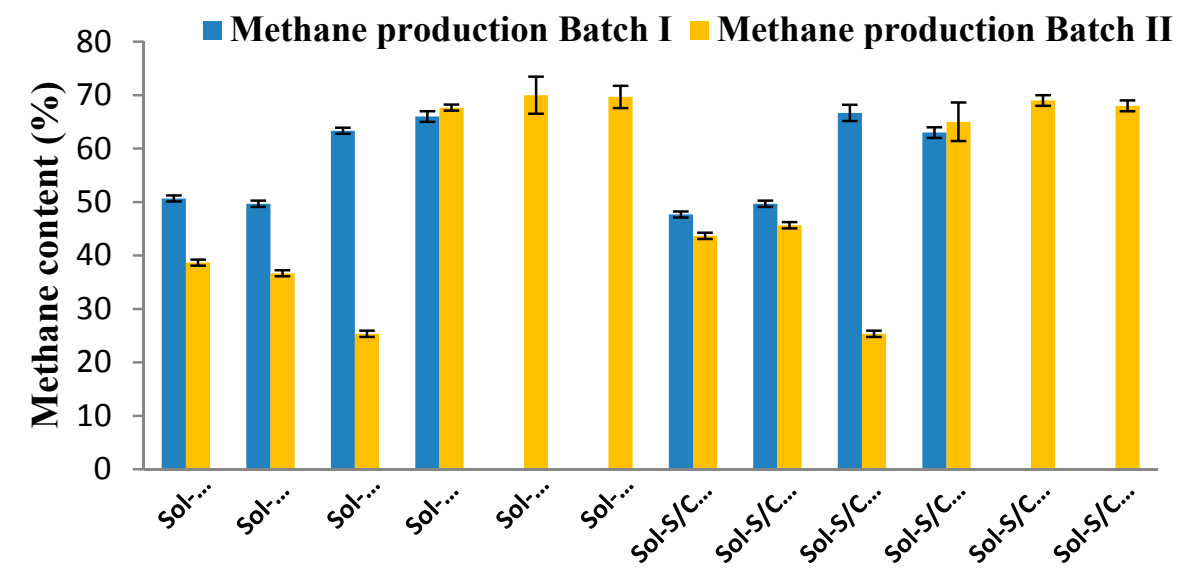

Figure 2. Methane content in biogas from solid residue of grass with cow dung (Sol-G/C), solid residue of silage with cow dung (Sol-S/C) pretreated by G, A, E, G+E, A+E and U.

\subsection{Production and Energy Yields}

In this study, the maximum HY from a co-digestion of grass with cow dung and silage with cow dung were 6.98 and $27.71 \mathrm{~mL} \mathrm{H}_{2} / \mathrm{g}$-VS $\mathrm{VS}_{\text {added, }}$, respectively (Figure 3). The MY of solid residues after the hydrogen production (Batch I) and solid residues after methane production (Batch II) pretreated by various pretreatment methods were depicted in Figure 3. The results suggested that various pretreatment methods resulted in the variation of MY (Figure 3). The maximum MY of 210.10 and $177.79 \mathrm{~mL} \mathrm{CH}_{4} / \mathrm{g}-\mathrm{VS}_{\text {added }}$ (Batch I) from solid residue of a co-digestion of grass with cow dung and silage with cow dung, respectively, were obtained from enzymatic pretreatment and alkaline pretreatment, respectively (Figure 3). The maximum MY of 370.39 and $370.99 \mathrm{~mL} \mathrm{CH}_{4} / \mathrm{g}-\mathrm{VS}_{\text {added }}$ (Batch II) from solid residue of co-digestion of grass with cow dung and silage with cow dung, 
respectively, were obtained from pre-treated solid residues by alkaline plus enzyme pretreatment (Figure 3). Untreated samples gave a lower MY in the range of $1.72-3.65 \mathrm{~mL} \mathrm{CH}_{4} / \mathrm{g}$-VS added for both substrates. The results indicated that the pretreatment methods increased the MY from a co-digestion of grass with cow dung and silage with cow dung. Moreover, the combined pretreatment methods gave benefits in terms of enhancing the yield and energy.

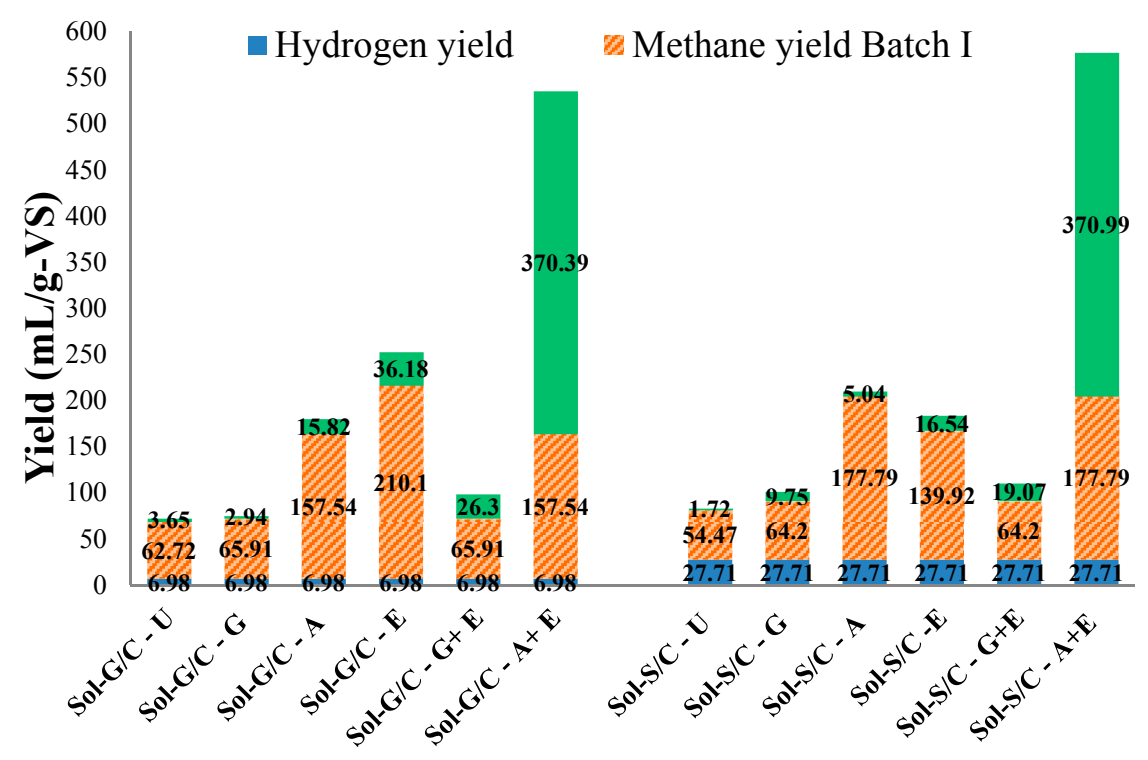

Figure 3. Overall hydrogen and MYs from two-stage bio-hydrogen and methane production from a co-digestion of grass with cow dung $(\mathrm{G} / \mathrm{C})$ and silage with cow dung $(\mathrm{S} / \mathrm{C})$. Solid residue of grass with cow dung (Sol-G/C), solid residue of silage with cow dung (Sol-S/C) pretreated by G, A, E, G+E, $\mathrm{A}+\mathrm{E}$ and $\mathrm{U}$.

The two-stage hydrogen and methane production (Batch I and Batch II) from the co-digestion of grass with cow dung and silage with cow dung are showed in Table 4 . The results indicated that the two-stage process resulted in an increase in energy yields from 0.09 to $480.27 \mathrm{MJ} / \mathrm{g}$-VS added and 0.36 to $204.70 \mathrm{MJ} / \mathrm{g}-\mathrm{VS}_{\text {added }}$ for a co-digestion of grass with cow dung and silage with cow dung, respectively (Table 4). The results revealed that alkaline plus enzyme pretreatment in the present study efficiently improved the MY in the two-stage process. The energy yield obtained from the co-digestion of grass with cow dung and silage with cow dung using a two-stage process was higher than the one-stage methane production process. In a two-stage process, MY was derived from the methane production process of solid residues left over after the hydrogen fermentation process (Batch I) plus from solid residues left over after the methane fermentation process (Batch II). Moreover, two-stage methane production from hydrogenic effluent from a co-digestion of grass with cow dung and silage with cow dung gave the maximum energy yield of 2.01 and $1.81 \mathrm{MJ} / \mathrm{g} \mathrm{VS}_{\text {added, }}$, respectively. Thus, two-stage hydrogen and methane production increased the total energy yield. Moreover, solid residues after hydrogen and methane production could be used as the substrate for methane production by anaerobic mixed cultures. Consequently, the total energy yield can be increased. However, the comparison of the energy yield revealed that the two-stage fermentation of a co-digestion of grass with cow dung had a higher energy yield of $480.27 \mathrm{MJ} / \mathrm{g}$-VS $\mathrm{Vdded}_{\text {add }}$ than the two-stage fermentation of co-digestion of silage with cow dung (204.70 MJ/g-VS added $)$. In addition, the COD at the end of fermentation process are reduced. 
Table 4. Energy yield from two-stage bio-hydrogen and methane production.

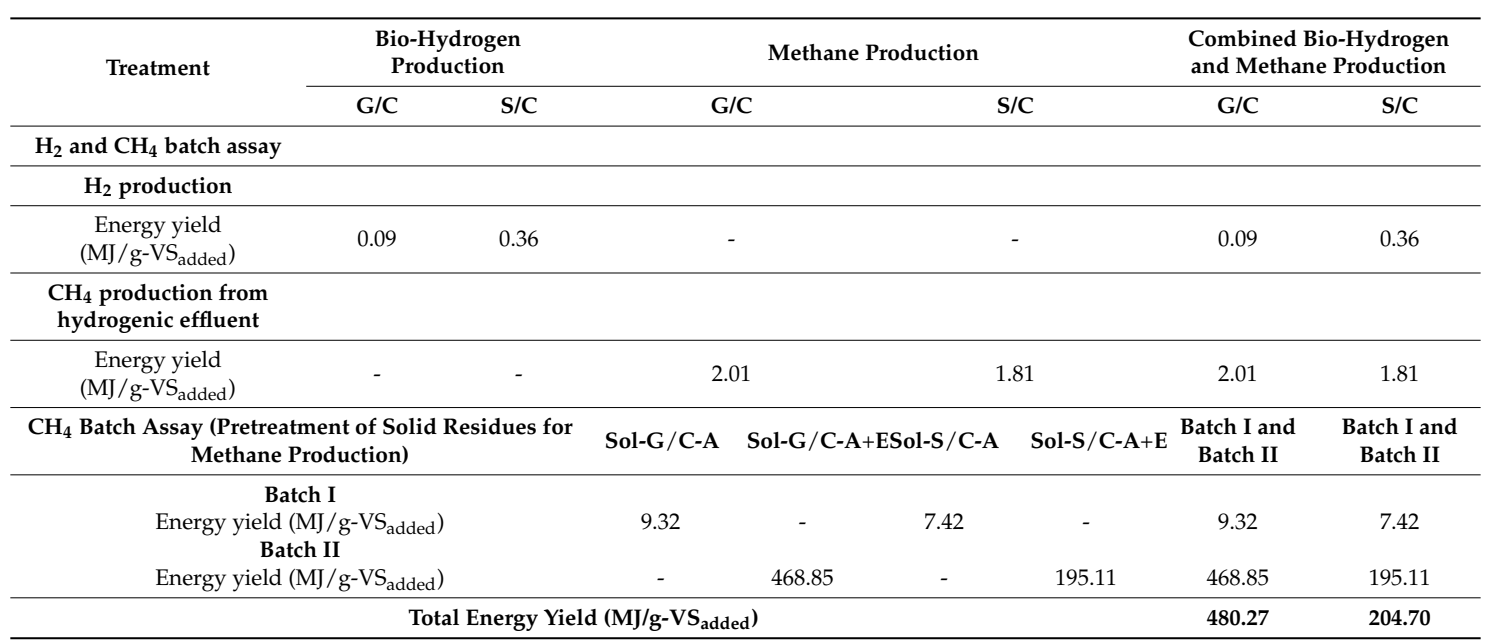

G/C: Co-digestion of grass with cow dung, S/C: Co-digestion of silage with cow dung; Energy yield was calculated based on the hydrogen and MY.

\section{Materials and Methods}

\subsection{Substrates}

Forty-five day old grass was cut $10 \mathrm{~cm}$ above ground. It was obtained from a local field in Khon Kaen province, Thailand. The preparation of silage followed the method of our previous experiment [50]. Grass and its silage were kept at $-20{ }^{\circ} \mathrm{C}$. Prior to usage, both substrates were thawed at room temperature $\left(30 \pm 2{ }^{\circ} \mathrm{C}\right)$ and chopped to a particle size of $0.5-1.0 \mathrm{~cm}$ in length by using a food blender. Cow dung was obtained from a farm of Faculty of Agriculture, Khon Kaen University, Khon Kaen, Thailand. It was refrigerated at $4{ }^{\circ} \mathrm{C}$ before use. The compositions of grass, silage and cow dung are tabulated in Table 5.

Table 5. Characteristics of feedstock and anaerobic sludge.

\begin{tabular}{ccccc}
\hline Characteristic & Grass & Silage & Cow Dung & Anaerobic Sludge \\
\hline Total solid (TS) & $0.25^{\mathrm{a}}$ & $0.42^{\mathrm{a}}$ & $0.26^{\mathrm{a}}$ & $0.07^{\mathrm{a}}$ \\
Volatile solid (VS) & $0.21^{\mathrm{a}}$ & $0.38^{\mathrm{a}}$ & $0.21^{\mathrm{a}}$ & $0.04^{\mathrm{a}}$ \\
Moisture (\%) & 76.01 & 70.65 & 79.58 & 93.49 \\
pH & 5.84 & 3.84 & 8.28 & 7.89 \\
Ash (\%) & 2.49 & 3.36 & 5.05 & 2.78 \\
Cellulose (\%) & 26.35 & 31.95 & 24.49 & ND \\
Hemicellulose (\%) & 17.26 & 19.93 & 26.62 & ND \\
Lignin (\%) & 31.25 & 32.22 & 25.73 & ND \\
Carbon (\%) & 45.36 & 43.18 & 37.64 & ND \\
Nitrogen (\%) & 0.78 & 0.92 & 1.81 & ND \\
C/N & 58.15 & 46.93 & 20.80 & \\
\hline
\end{tabular}

ND: not determined, ${ }^{a}$ : unit in $\mathrm{g} / \mathrm{g}$-dry weight, all measurements were done in triplicates.

\subsection{Inoculum}

C. butyricum TISTR 1032 used as the inoculum for hydrogen production was purchased from the Thailand Institute of Scientific and Technological Research (TISTR), Bangkok, Thailand. The cultivation protocol was conducted by following the method of Pattra et al. [42]. Briefly, C. butyricum was activated by transferring $1 \mathrm{~mL}$ of the stock culture at a cell concentration of $10^{7}$ cells $/ \mathrm{mL}$ into $10 \mathrm{~mL}$ Tryptone sucrose yeast extract (TSY) medium, incubated at $37^{\circ} \mathrm{C}$ for $10 \mathrm{~h}$. The culture was further enriched by 
inoculating $10 \% v / v$, cell concentration of $10^{6}$ cells $/ \mathrm{mL}$, of the culture into $60 \mathrm{~mL}$ TSY medium and incubated at the given conditions before being used as inoculum.

Anaerobic sludge used to produce methane was obtained from a biogas plant of SF Khon Kaen Co., Ltd. (Khon Kaen, Thailand). The biogas plant produces methane from a co-digestion of silage and chicken manure. The anaerobic sludge was cultivated using $10 \mathrm{~g} / \mathrm{L}$ glucose as a carbon source and then incubated at room temperature $\left(30 \pm 2{ }^{\circ} \mathrm{C}\right)$. The fermentation was continued until the gas production ceased. This was conducted to ensure that there was no self-fermentation of the inoculum. After the fermentation ceased, the seed cultures were thoroughly mixed and filtered through a thin layer of cloth before being used as inoculum. The characteristics of the anaerobic sludge are presented in Table 5 .

\subsection{Bio-Hydrogen Production from Co-Digestion of Grass and Silage with Cow Dung by C. butyricum TISTR 1032 (First Stage)}

Batch fermentation of hydrogen was conducted at the fixed ratio of grass with cow dung and silage with cow dung of 3:1 (g-VS/g-VS). The mixing ratio was achieved by holding the cow dung constant at $10 \mathrm{~g}$-VS/L while grass and silage were held at $30 \mathrm{~g}$-VS/L. C. butyricum TISTR 1032 was used as the inoculum at $20 \%(\mathrm{v} / \mathrm{v})$. The fermentations were conducted in $120 \mathrm{~mL}$ serum bottles with a working volume of $70 \mathrm{~mL}$. A modified basic anaerobic (BA) medium [51] was supplied to each bottle for making up a working volume to $70 \mathrm{~mL}$. The initial $\mathrm{pH}$ was adjusted to 6 by $5 \mathrm{M} \mathrm{HCl}$ or $5 \mathrm{M} \mathrm{NaOH}$. After capping with rubber stoppers and aluminum caps, the headspace in serum bottles were purged with nitrogen gas for $10 \mathrm{~min}$ to create anaerobic conditions. The serum bottles were incubated at room temperature $\left(30 \pm 2{ }^{\circ} \mathrm{C}\right)$ on a continuous orbital shaker at $150 \mathrm{rpm}$. Controls were grass with cow dung and silage with cow dung without inoculum addition. All treatments were conducted in triplicate. The volume of biogas was measured during fermentation using a wetted glass syringe method [52]. The hydrogenic effluent and solid residues left over after the hydrogen fermentation process were further used as the substrate for methane production in the second stage. The solid residue was initially pretreated before being used as substrates for methane production.

\subsection{Methane Production from Hydrogenic Effluent and Solid Residues Left over after Bio-Hydrogen Production Process by Anaerobic Mixed Cultures (Second Stage)}

In this experiment, hydrogenic effluent and solid residues left over after hydrogen fermentation were used as substrates for methane production (Figure 4). Batch fermentations were conducted in $120 \mathrm{~mL}$ serum bottles with a working volume of $70 \mathrm{~mL}$, containing $65 \mathrm{~mL}$ of hydrogenic effluent from a co-digestion of grass with cow dung and silage with cow dung. Anaerobic sludge at $10 \mathrm{~g}-\mathrm{VS} / \mathrm{L}$ was used as inoculum. The fermentation broth was adjusted to the initial $\mathrm{pH}$ of 7.5 using $5 \mathrm{M} \mathrm{HCl}$ or $5 \mathrm{M} \mathrm{NaOH}$. The batch fermentation and gas volume were analyzed as outlined in Section 3.3. All treatments were conducted in triplicate.

Solid residue left over after hydrogen fermentation was separated from fermentation broth by being filtered through a thin layer of cloth and washed with distilled water three times and dried at $60^{\circ} \mathrm{C}$ for $24 \mathrm{~h}$. The dried solid residue was pretreated by grinding, alkaline pretreatment and enzyme pretreatment, as outlined in Section 3.6. The pretreated solid residues were used as the substrate for methane production (Batch I). The fermentation was conducted in $60 \mathrm{~mL}$ serum bottles with a working volume of $35 \mathrm{~mL}$. The solid residues at the concentrations of 13.56 and $19.17 \mathrm{~g}$-VS/L were obtained from the treatment of grass with cow dung and silage with cow dung, respectively, and were used as the substrate for methane production. A $10 \mathrm{~g}$-VS/L of anaerobic sludge was inoculated to each serum bottles as seed inoculum. The control experiment was conducted using untreated solid residue with anaerobic sludge. The batch fermentation, gas volume and the gas compositions were measured as previously described. 


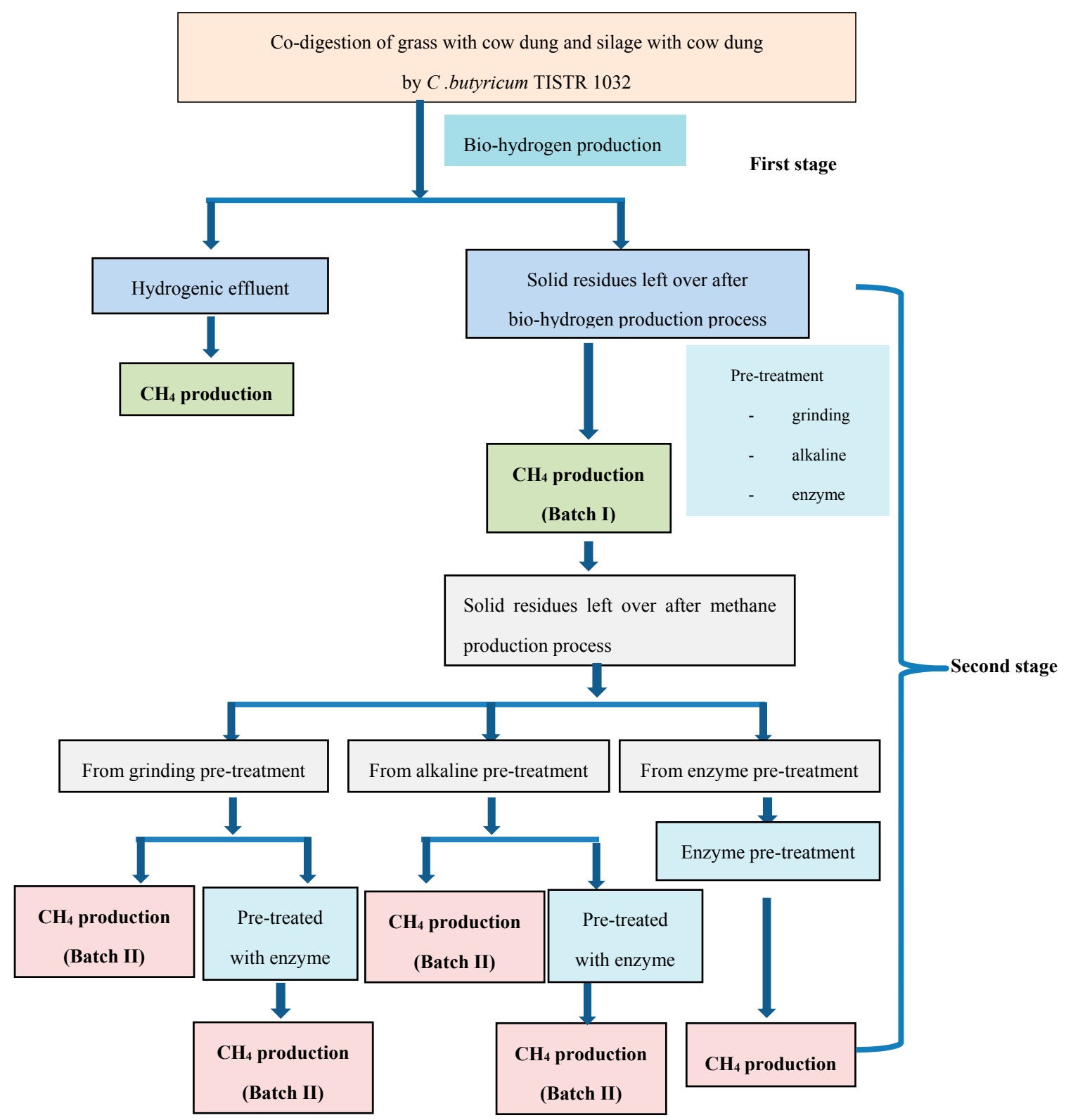

Figure 4. Schematic diagram of the research plan for the two-stage bio-hydrogen and methane production processes from the co-digestion of grass with cow dung and silage with cow dung.

\subsection{Methane Production from Solid Residues Left over after Methane Production Process (Batch I) by Anaerobic} Mixed Cultures

The solid residues left over after methane fermentation (Batch I) were pretreated before being repeatedly used as a substrate to produce methane (Batch II), as shown in Figure 4. This experiment was separated into three parts.

First, the solid residue left over after methane production (Batch I) was pretreated by grinding and the pretreatment was separated into two parts. The first part was repeatedly used as the substrate to produce methane by anaerobic mixed cultures. The second part was pretreated with the enzyme treatment method (or so-called grinding plus enzyme pretreatment) and further used as the substrate for methane production (Batch II).

Second, the solid residue pretreated with the alkaline treatment for methane production in Batch I was separated into two parts. The first part was repeatedly used as the substrate to produce methane 
by anaerobic mixed cultures. The second part was pretreated with the enzyme treatment method (or so-called alkaline plus enzyme pretreatment) before being used as the substrate for methane production (Batch II).

Third, the solid residue pretreated with the enzyme treatment for methane production in Batch I was pretreated one more time with the enzyme treatment method before being used as the substrate for methane production (Batch II).

Methane production from the pretreated solid residue obtained from the treatment of grass with cow dung and silage with cow dung were conducted in $60 \mathrm{~mL}$ serum bottles with a working volume of $35 \mathrm{~mL}$. The initial concentration of pretreated solid residue were 0.57 and $0.84 \mathrm{~g}$-VS/L, respectively. Anaerobic sludge at $10 \mathrm{~g}$-VS/L was used as inoculum. The control was untreated solid residue with the anaerobic sludge. The batch fermentation and gas volume were conducted as outlined in Section 3.3.

\subsection{Pretreatment Methods for Solid Residues}

Pretreatment methods of solid residue included grinding, alkaline pretreatment, enzyme pretreatment and a combined pretreatment of grinding plus enzyme, and alkaline plus enzyme. The individual pretreament and the combined pretreatment methods were set according to Prapinagsorn et al. [50].

\subsection{Analytical Methods}

TS, VS, moisture, carbon, nitrogen contents and total COD were determined in triplicate according to the standard method of American Public Health Association (APHA) [53]. The lignocellulosic components, including lignin, cellulose and hemicellulose, were determined following the method of Sluiter et al. [54]. The biogas compositions $\left(\mathrm{H}_{2}, \mathrm{CH}_{4}\right.$ and $\left.\mathrm{CO}_{2}\right)$ were determined using gas chromatography (GC, Shimadzu 2014). Operating conditions were set according to our previous experiment [50].

The cumulative hydrogen and methane production were calculated from the headspace measurement of gas compositions and the total volume of hydrogen and methane produced at each time interval. They were calculated using a mass balance equation $[55,56]$. The modified Gompertz equation was applied to determine the biogas production potential, biogas production rate, and lag phase (Equation (1)) [57].

$$
H, M(t)=\operatorname{Pexp}\left\{-\exp \left(\frac{R_{m e}}{P}(\lambda-t)\right)+1\right\}
$$

where, $H, M$, cumulative of hydrogen and methane production $(\mathrm{mL} / \mathrm{L}) ; P$, hydrogen and methane production potential $(\mathrm{mL} / \mathrm{L}) ; R_{m}$, maximum hydrogen and methane production rate $(\mathrm{mL} / \mathrm{L} \cdot \mathrm{h}) ; \lambda$, lag phase time (h); $t$, incubation time (h) and $e$ is 2.71828 .

The energy yield from hydrogen and methane were calculated as described by Reungsang et al. [58].

\section{Conclusions}

The co-digestion of grass or silage with cow dung is a good approach for two-stage hydrogen and methane production. The maximum HP and $\mathrm{HY}$ of $554 \mathrm{~mL} \mathrm{H}_{2} / \mathrm{L}$ and $27.71 \mathrm{~mL} \mathrm{H}_{2} / \mathrm{g}-\mathrm{VS}_{\text {added }}$ were obtained from the co-digestion of silage with cow dung by C. butyricum TISTR 1032, indicating that C. butyricum TISTR 1032 enhanced the HP and HY. The hydrogenic effluent and solid residues left over after hydrogen fermentation were demonstrated to be good feedstock for methane production. The maximum MP of 902 and $1002 \mathrm{~mL} \mathrm{CH}_{4} / \mathrm{L}$ were obtained from hydrogenic effluent from a co-digestion of grass with cow dung and silage with cow dung, respectively. The maximum MY of 370.39 and $370.99 \mathrm{~mL} \mathrm{CH}_{4} / \mathrm{g}-\mathrm{VS}_{\text {added }}$ were obtained from solid residue obtained from a co-digestion of grass with cow dung and silage with cow dung pretreated by alkaline plus enzyme. The energy yield from the two-stage fermentation of a co-digestion of grass with cow dung and silage with cow dung were 480.27 and $204.70 \mathrm{MJ} / \mathrm{g}-\mathrm{VS}_{\text {added }}$, respectively. Based on these results, the application of 
two-stage hydrogen and methane production from the co-digestion of grass with cow dung was more promising than a co-digestion of silage with cow dung due to the high energy obtained. Additionally, our approach demonstrates an efficient way to completely utilize grass and silage to produce methane and to minimize the amount of waste at the end of the anaerobic digestion process.

Acknowledgments: The authors appreciate the research fund from Energy Conservation Promotion Fund, Energy Policy and Planning Office, Ministry of Energy, Thailand, and TRF Senior Research Scholar (Grant No. RTA5980004). The scholarship for Wipa Prapinagsorn was kindly provided by Uttaradit Rajabhat University.

Author Contributions: Alissara Reungsang conceived, designed the experiments, corrected and revised the manuscript; Wipa Prapinagsorn performed the experiments; Wipa Prapinagsorn and Sureewan Sittijunda analyzed the data; Wipa Prapinagsorn and Sureewan Sittijunda drafted the manuscript. All the authors have read, corrected, and approved the manuscript.

Conflicts of Interest: The authors declare no conflict of interest.

\section{Nomenclature}

\begin{tabular}{|c|c|}
\hline A & alkaline pretreatment \\
\hline $\mathrm{AD}$ & anaerobic digestion \\
\hline $\mathrm{A}+\mathrm{E}$ & alkaline plus enzyme pretreatment \\
\hline BA & basic anaerobic \\
\hline $\mathrm{C} / \mathrm{N}$ & ratio carbon to nitrogen ratio \\
\hline COD & chemical oxygen demand \\
\hline $\mathrm{E}$ & enzyme pretreatment \\
\hline Eff-G/C & hydrogenic effluent from co-digestion of grass with cow dung \\
\hline Eff-S/C & hydrogenic effluent from co-digestion of silage with cow dung \\
\hline FPU & filter paper unit \\
\hline G & grinding \\
\hline GC & gas chromatography \\
\hline $\mathrm{G} / \mathrm{C}$ & co-digestion of grass with cow dung \\
\hline $\mathrm{G}+\mathrm{E}$ & grinding plus enzyme pretreatment \\
\hline HP & hydrogen production potential $\left(\mathrm{mL} \mathrm{H}_{2} / \mathrm{L}\right)$ \\
\hline HPR & hydrogen production rate $\left(\mathrm{mL} \mathrm{H}_{2}\right) / \mathrm{L} \cdot(\mathrm{h})$ \\
\hline HY & hydrogen yield $\left(\mathrm{mL} \mathrm{H}_{2} / \mathrm{g}-\mathrm{VS}_{\text {added }}\right)$ \\
\hline MP & methane production $\left(\mathrm{mL} \mathrm{CH}_{4} / \mathrm{L}\right)$ \\
\hline MY & methane yield $\left(\mathrm{mL} \mathrm{CH}_{4} / \mathrm{g}-\mathrm{VS}_{\text {added }}\right)$ \\
\hline$R m$ & methane production rate $\left(\mathrm{mL} \mathrm{CH}_{4}\right) / \mathrm{L} \cdot(\mathrm{h})$ \\
\hline $\mathrm{S} / \mathrm{C}$ & co-digestion of silage with cow dung \\
\hline SMPs & soluble metabolite products $(\mathrm{g} / \mathrm{L})$ \\
\hline Sol-G/C & solid residue of grass with cow dung \\
\hline Sol-S/C & solid residue of silage with cow dung \\
\hline TCD & thermal conductivity detector \\
\hline TS & total solid (g/g-dry weight) \\
\hline TSY & tryptone sucrose yeast extract \\
\hline TVFAs & total volatile fatty acids (g/L) \\
\hline $\mathrm{U}$ & untreated solid residue \\
\hline VFAs & volatile fatty acids (g/L) \\
\hline VS & volatile solid (g/g-dry weight) \\
\hline
\end{tabular}

\section{References}

1. Edwards, P.; Kuznetsov, V.; David, W.; Brandon, N. Hydrogen and fuel cells: Towards a sustainable energy future. Energy Policy 2008, 36, 4356-4362. [CrossRef]

2. Liu, X.; Li, R.; Ji, M.; Han, L. Hydrogen and methane production by co-digestion of waste activated sludge and food waste in the two-stage fermentation process: Substrate conversion and energy yield. Bioresour. Technol. 2013, 146, 317-323. [CrossRef] [PubMed] 
3. Antonopoulou, G.; Gavala, H.N.; Skiadas, I.V.; Lyberatos, G. Effect of substrate concentration on fermentative hydrogen production from sweet sorghum extract. Int. J. Hydrogen Energy 2011, 36, 4843-4851. [CrossRef]

4. Jung, K.W.; Kim, D.H.; Shin, H.S. Continuous fermentative hydrogen and methane production from Laminaria japonica using a two-stage fermentation system with recycling of methane fermented effluent. Int. J. Hydrogen Energy 2012, 37, 5648-5657. [CrossRef]

5. Shi, X.; Kim, D.H.; Shin, H.S.; Jung, K.W. Effect of temperature on continuous fermentative hydrogen production from Laminaria japonica by anaerobic mixed cultures. Bioresour. Technol. 2013, 144, 225-231. [CrossRef] [PubMed]

6. Ma, Z.; Li, C.; Su, H. Dark bio-hydrogen fermentation by an immobilized mixed culture of Bacillus cereus and Brevumdimonas naejangsanensis. Renew. Energy 2017, 105, 458-464. [CrossRef]

7. Maintinguer, S.I.; Lazaro, C.Z.; Pachiega, R.; Varesche, M.B.A.; Sequinel, R.; Oliveira, J.E. Hydrogen bioproduction with Enterobacter sp. isolated from brewery wastewater. Int. J. Hydrogen Energy 2017, 42, 152-160. [CrossRef]

8. Wan, J.; Jing, Y.; Zhang, S.; Angelidaki, I.; Luo, G. Mesophilic and thermophilic alkaline fermentation of waste activated sludge for hydrogen production: Focusing on homoacetogenesis. Water Res. 2016, 102, 524-532. [CrossRef] [PubMed]

9. Ghimire, A.; Sposito, F.; Frunzo, L.; Trably, E.; Escudié, R.; Pirozzi, F.; Lens, P.N.L.; Esposito, G. Effects of operational parameters on dark fermentative hydrogen production from biodegradable complex waste biomass. Waste Manag. 2016, 50, 55-64. [CrossRef] [PubMed]

10. Cheng, J.; Ding, L.; Lin, R.; Liu, M.; Zhou, C.K. Physicochemical characterization of typical municipal solid wastes. Energy Convers. Manag. 2016, 117, 297-304. [CrossRef]

11. Han, W.; Hu, Y.; Li, S.; Huang, J.; Nie, N.; Zhao, H.; Tang, J. Simultaneous dark fermentative hydrogen and ethanol production from waste bread in a mixed packed tank reactor. J. Clean. Prod. 2017, 141, 608611. [CrossRef]

12. Gonzales, R.R.; Sivagurunathan, P.; Parthiban, A.; Kim, S.H. Optimization of substrate concentration of dilute acid hydrolyzate of lignocellulosic biomass in batch hydrogen production. Int. Biodeterior. Biodegrad. 2016, 113, 22-27. [CrossRef]

13. Reddy, K.O.; Maheswari, C.U.; Shukla, M.; Rajulu, A.V. Chemical composition and structural characterization of Napier grass fibers. Mater. Lett. 2012, 67, 35-38. [CrossRef]

14. Lu, Q.L.; Tang, L.R.; Wang, S.; Huang, B.; Chen, Y.D.; Chen, X.R. An investigation on the characteristics of cellulose nanocrystals from Pennisetum sinese. Biomass Bioenergy 2014, 70, 267-272. [CrossRef]

15. Phitsuwan, P.; Charupongrat, S.; Klednark, R.; Ratanakhanokchai, K. Structural features and enzymatic digestibility of Napier grass fibre treated with aqueous ammonia. J. Ind. Eng. Chem. 2015, 32, 360-364. [CrossRef]

16. Sawasdee, V.; Pisutpaisal, N. Feasibility of Biogas Production from Napier Grass. Energy Procedia 2014, 61, 1229-1233. [CrossRef]

17. Dussadee, N.; Reansuwan, K.; Ramaraj, R. Potential development of compressed bio-methane Gas Production from pig farms and elephant grass silage for transportation in Thailand. Bioresour. Technol. 2014, 155, 438-441. [CrossRef] [PubMed]

18. Seppälä, M.; Laine, A.; Rintala, J. Screening of novel plants for biogas production in northern conditions. Bioresour. Technol. 2013, 139, 355-362. [CrossRef] [PubMed]

19. Pu, Y.; Zhang, D.; Singh, P.M.; Ragauskas, A.J. The new forestry biofuels sector. Biofuels Bioprod. Biorefin. 2008, 2, 58-73. [CrossRef]

20. Saha, B.C. Hemicellulose bioconversion. Microbiol. Biotechnol. 2003, 30, 279-326. [CrossRef] [PubMed]

21. Ren, N.; Wang, A.; Cao, G.; Xu, J.; Gao, L. Bioconversion of lignocellulosic biomass to hydrogen: Potential and challenges. Biotechnol. Adv. 2009, 27, 1051-1060. [CrossRef] [PubMed]

22. Strezov, V.; Evans, T.J.; Hayman, C. Thermal conversion of elephant grass (Pennisetum Purpureum Schum) to bio-gas, bio-oil and charcoal. Bioresour. Technol. 2008, 99, 8394-8399. [CrossRef] [PubMed]

23. Himmel, M.E.; Ding, S.Y.; Johnson, D.K.; Adney, W.S.; Nimlos, M.R.; Brady, J.W.; Foust, T. Biomass recalcitrance: Engineering plants and enzymes for biofuels yield. Science 2007, 315, 804-807. [CrossRef] [PubMed]

24. Ye, J.; Li, D.; Sun, Y.; Wang, G.; Yuan, Z.; Zhen, F.; Wang, Y. Improved biogas production from rice straw by co-digestion with kitchen waste and pig manure. Waste Manag. 2013, 33, 2653-2658. [CrossRef] [PubMed] 
25. Li, Y.; Zhang, R.H.; Liu, X.Y.; Chen, C.; Xiao, X.; Feng, L.; He, Y.F.; Liu, G.Q. Evaluating methane production from anaerobic mono and co-digestion of kitchen waste, corn stover, and chicken manure. Energy Fuels 2013, 27, 2085-2091. [CrossRef]

26. Li, Y.; Li, Y.; Zhang, D.; Li, G.; Lu, J.; Li, S. Solid state anaerobic co-digestion of tomato residues with dairy manure and corn stover for biogas production. Bioresour. Technol. 2016, 217, 50-55. [CrossRef] [PubMed]

27. Xie, X.M.; Zhang, X.Q.; Dong, Z.X.; Guo, H.R. Dynamic changes of lignin contents of MT-1 elephant grass and its closely related cultivars. Biomass Bioenergy 2011, 35, 1732-1738. [CrossRef]

28. Pakarinen, O.; Tahti, P.; Rintala, J. One-stage $\mathrm{H}_{2}$ and $\mathrm{CH}_{4}$ and two-stage $\mathrm{H}_{2}$ and $\mathrm{CH}_{4}$ production from grass silage and from solid and liquid fractions of $\mathrm{NaOH}$ pre-treated grass silage. Biomass Bioenergy 2009, 33, 1419-1427. [CrossRef]

29. Cavinato, C.; Bolzonella, D.; Eusebi, A.L.; Pavan, P. Bio-hythane production by thermophilic two-phase anaerobic digestion of organic fraction of municipal solid waste: Preliminary results. In AIDIC Conference Series; AIDIC: Milan, Italy, 2009; Volume 9, p. 166.

30. Surendra, K.C.; Khanal, S.K. Effects of crop maturity and size reduction on digestibility and methane yield of dedicated energy crop. Bioresour. Technol. 2015, 178, 187-193. [CrossRef] [PubMed]

31. Behera, S.; Arora, R.; Nandhagopal, N.; Kumar, S. Importance of chemical pretreatment for bioconversion of lignocellulosic biomass. Renew. Sustain. Energy Rev. 2014, 36, 91-106. [CrossRef]

32. Lin, R.; Cheng, J.; Song, W.; Ding, L.; Xie, B.; Zhou, J.; Cen, K. Characterisation of water hyacinth with microwave-heated alkali pretreatment for enhanced enzymatic digestibility and hydrogen/methane fermentation. Bioresour. Technol. 2015, 182, 1-7. [CrossRef] [PubMed]

33. He, Y.C.; Ding, Y.; Xue, Y.F.; Yang, B.; Liu, F.; Wang, C.; Zhu, Z.Z.; Qing, Q.; Wu, H.; Zhu, C.; et al. Enhancement of enzymatic saccharification of corn stover with sequential Fenton pretreatment and dilute $\mathrm{NaOH}$ extraction. Bioresour. Technol. 2015, 193, 324-330. [CrossRef] [PubMed]

34. Nissila, M.E.; Lay, C.; Puhakka, J. Dark fermentative hydrogen production from lignocellulosic hydrolyzates. A review. Biomass Bioenergy 2014, 67, 145-159. [CrossRef]

35. Rabemanolontsoa, H.; Saka, S. Various pretreatments of lignocellulosics. Bioresour. Technol. 2016, 199 , 83-91. [CrossRef] [PubMed]

36. Michalska, K.; Bizukoj, M.; Ledakowicz, S. Pretreatment of energy crops with sodium hydroxide and cellulolytic enzymes to increase biogas production. Biomass Bioenergy 2015, 80, 213-221. [CrossRef]

37. Kaur, K.; Phutela, U.G. Enhancement of paddy straw digestibility and biogas production by sodium hydroxide-microwave pretreatment. Renew. Energy 2016, 92, 178-184. [CrossRef]

38. Mustafa, A.M.; Poulsen, T.G.; Xia, X.; Sheng, K. Combinations of fungal and milling pretreatments for enhancing rice straw biogas production during solid-state anaerobic digestion. Bioresour. Technol. 2017, 224, 174-182. [CrossRef] [PubMed]

39. Zheng, Y.; Zhao, J.; Xu, F.; Li, Y. Pretreatment of lignocellulosic biomass for enhanced biogas production. Prog. Energy Combust. Sci. 2014, 42, 35-53. [CrossRef]

40. Thomas, L.; Joseph, A.; Gottumukkala, L.D. Xylanase and cellulase systems of Clostridium sp.: An insight on molecular approaches for strain improvement. Bioresour. Technol. 2014, 158, 343-350. [CrossRef] [PubMed]

41. Nualsri, C.; Reungsanga, A.; Plangklang, P. Biochemical hydrogen and methane potential of sugarcane syrup using a two-stage anaerobic fermentation process. Ind. Crops Prod. 2016, 82, 88-99. [CrossRef]

42. Pattra, S.; Lay, C.H.; Lin, C.Y.; O-Thong, S.; Reungsang, A. Performance and population analysis of hydrogen production from sugarcane juice by non-sterile continuous stirred tank reactor augmented with Clostridium butyricum. Int. J. Hydrogen Energy 2011, 36, 8697-8703. [CrossRef]

43. Rafieenia, R.; Chaganti, S.R. Flux balance analysis of different carbon source fermentation with hydrogen producing Clostridium butyricum using Cell Net Analyzer. Bioresour. Technol. 2015, 175, 613-618. [CrossRef] [PubMed]

44. Chandra, R.; Takeuchi, H.; Hasegawa, T. Methane production from lignocellulosic agricultural crop wastes: A review in context to second generation of biofuel production. Renew. Sustain. Energy Rev. 2012, 16, 1462-1476. [CrossRef]

45. Zhai, N.; Zhang, T.; Yin, D.; Yang, G.; Wang, X.; Ren, G.; Feng, Y. Effect of initial pH on anaerobic co-digestion of kitchen waste and cow manure. Waste Manag. 2015, 38, 126-131. [CrossRef] [PubMed] 
46. Zhao, L.; Cao, G.L.; Wang, A.J.; Ren, H.Y.; Zhang, K.; Ren, N.Q. Consolidated bioprocessing performance of Thermoanaerobacterium thermosaccharolyticum M18 on fungal pretreated cornstalk for enhanced hydrogen production. Biotechnol. Biofuels 2014, 7, 178. [CrossRef] [PubMed]

47. Salehian, P.; Karimi, K. Alkali pretreatment for improvement of biogas and ethanol production from different waste parts of pine tree. Ind. Eng. Chem. Res. 2013, 52, 972-978. [CrossRef]

48. Frigon, J.C.; Mehta, P.; Guiot, S.R. Impact of mechanical, chemical and enzymatic pretreatments on the methane yield from the anaerobic digestion of switch grass. Biomass Bioenergy 2012, 36, 1-11. [CrossRef]

49. Sun, Y.; Cheng, J. Hydrolysis of lignocellulosic materials for ethanol production: Review. Bioresour. Technol. 2002, 83, 1-11. [CrossRef]

50. Prapinagsorn, W.; Sittijunda, S.; Reungsang, A. Co-Digestion of Napier Grass and Its Silage with Cow Dung for Methane Production. Energies 2017, 10, 1654. [CrossRef]

51. Fangkum, A.; Reungsang, A. Biohydrogen production from mixed xylose/arabinose at thermophilic temperature by anaerobic mixed cultures in elephant dung. Int. J. Hydrogen Energy 2011, 36, 13928-13938. [CrossRef]

52. Owen, W.; Stuckey, C.; Healy, J.; Young, L.; McCarty, P. Bioassay for monitoring biochemical methane potential and anaerobic toxicity. Water Res. 1979, 13, 485-492. [CrossRef]

53. American Public Health Association (APHA). Standard Methods for Examination of Water and Wastewater, 18th ed.; American Public Health Association: Washington, DC, USA, 1995.

54. Sluiter, A.; Hames, B.; Ruiz, R.; Scarlata, C.; Sluiter, J.; Templeton, D.; Crocker, D. Determination of Structural Carbohydrates and Lignin in Biomass; National Renewable Energy Laboratory: Golden, CO, USA, 2008; pp. 1-18.

55. Zheng, X.J.; Yu, H.Q. Inhibitory effects of butyrate on biological hydrogen production with mixed anaerobic culturees. J. Environ. Manag. 2005, 74, 65-70. [CrossRef] [PubMed]

56. Lopez, S.; Dhanoa, M.S.; Dijkstra, J.; Bannink, A.; Kebreab, E.; France, J. Some methodological and analytical considerations regarding application of the gas production technique. Anim. Feed Sci. Technol. 2007, 135, 139-156. [CrossRef]

57. Zwietering, M.H.; Jongenburger, L.; Rombouts, F.M.; Van't, R.K. Modeling the bacterial growth curve. Appl. Environ. Microbiol. 1990, 64, 1878-1883.

58. Reungsang, A.; Pattra, S.; Sittijunda, S. Optimization of Key Factors Affecting Methane Production from Acidic Effluent Coming from the Sugarcane Juice Hydrogen Fermentation Process. Energies 2012, 5, 4746-4757. [CrossRef] 